\title{
Regulation of the Sale of Property Insurance by Savings and Loan Associations
}

Savings and loan associations, ${ }^{1}$ the nation's primary source of residential credit, ${ }^{2}$ nearly always precondition approval of a mortgage upon the borrower's purchase of property insurance ${ }^{3}$ on the real estate securing the loan. ${ }^{4}$ Association personnel frequently apply subtle pressures to channel that insurance purchase through an insurance agency owned by the officers or directors of the association, 5 a practice that may entail the appropriation of a corporate opportunity. ${ }^{6}$ This phenomenon is due in part to restrictions under state law that may prevent the association itself from acting as an insurance agent. ${ }^{7}$ The restrictions fall into four general categories: statutes providing general qualifications for insurance agents; antirebate statutes; controlled business statutes; and primary occupation statutes.

This comment first surveys existing state regulation to determine the situations in which savings and loan associations or af-

1. There are two types of savings and loan associations: mutual and stock. A mutual association obtains its capital from its depositors, who are also its owners. In a stock association, the stockholders contribute capital in exchange for an ownership interest in the association. The stock association's owners need not be saver-depositors and frequently are not. Twenty-one states permit the chartering of stock associations. ABA Committee on Savings and Loan Associations, Handbook of Savings and Loan Law 12-14 (1973). At the end of 1973, mutual associations represented eighty-seven percent of all associations and held approximately seventy-nine percent of the industry's assets. U.S. Savings and Loan League, 1974 Savings and Loan Fact Book 60 [hereinafter cited as FACT Bóok].

2. At the end of 1973 , savings and loan mortgages accounted for $\mathbf{4 4 . 3}$ percent of the total outstanding residential mortgages. Other significant sources were commercial banks, life insurance companies, and mutual savings banks. FACT Book, supra note 1 , at 35 .

3. Property insurance usually includes protection against one or more of the following hazards: fire, lightning, smoke, windstorm, water leakage, hail, riots, rain, earthquakes, and explosions. McCullough, Property Insurance, 1963 INs. L.J. 75, 76-77.

4. The most frequently required protection is fire insurance. Herman, Conflict of Interest in the Savings and Loan Industry, in 2 STUdy of THE Savings and LOAN INDUSTRY 847 (I. Friend ed. 1969). The right of an association to demand this coverage is well established. See Eddy v. Home Fed. Sav. \& Loan Ass'n, 60 Cal. App. 2d 42, 45, 140 P.2d 156, 158 (1943).

5. See Herman, supra note 4, at 854-55.

6. See Goodman v. Perpetual Bldg. Ass'n, 320 F. Supp. 20 (D.D.C. 1970); Kerrigan v. Unity Sav. Ass'n, 58 Ill. 2d 20. 317 N.E.2d 39 (1974); $c f$. Diedrick v. Helm, 217 Minn. 483, 14 N.W.2d 913 (1944).

7. An agent represents a specific company under an agency contract. See Kimball \& Jackson, The Regulation of Insurance Marketing, 61 Colum. L. REv. 141, 167 (1961). 
filiated agencies ${ }^{8}$ are directly prohibited from selling property insurance and those in which they would be indirectly prohibited from doing so under arguably applicable insurance statutes. The comment argues that the latter should be construed to permit savings and loans to qualify as property insurance agents. It then analyzes the effects of allowing savings and loans to act as insurance agents and concludes that there are strong policy reasons for eliminating direct prohibitions of that activity.

\section{Existing Statutes}

The power of a savings and loan association to act as an insurance agent is initially a function of the source of its charter, since the powers granted to federally chartered associations by the federal government may differ from those granted to state chartered associations by the states. In addition, regulation of the sale of property insurance by a savings and loan association may vary depending on whether the sale is made by the association itself, by a service corporation in which the association has invested, or by a subsidiary of a savings and loan holding company. Thus, analysis of existing regulation of the sale property insurance by savings and loan associations must identify both the source of the charter and the identity of the sales agent.

\section{A. State Chartered Savings and Loan Associations}

1. The Association as an Insurance Agent. Although most savings and loan association charters ${ }^{9}$ do not expressly grant the power to sell insurance, ${ }^{10}$ courts have held that an association's incidental powers-those reasonably necessary to accomplish an association's express objectives ${ }^{11}$ _include the power to sell property insurance

8. The term affiliated agencies will be used in this comment to refer to service corporations, subsidiaries of savings and loan holding companies, and agencies owned by officers and directors of the association.

9. State chartered savings and loan associations are nearly always in corporate form. In re Puget Sound Sav. \& Loan Ass'n, 49 F.2d 922, 923-24 (W.D. Wash. 1931); Orlando v. Nix, 171 La. 176, 179, 129 So. 810, 811 (1930); Sundt v. Mutual Bldg. \& Loan Ass'n, 37 N.M. 1, 4, 16 P.2d 394, 395 (1932); 1 W. Fletcher, Private Corporations $\$ 76$ (rev. ed. 1963); Prather, Savings Accounts in Savings and Loan Associations, 15 Bus. LAw. 44, 51 (1959).

10. Conversation with Mr. Donald Weeks, Assistant Counsel, U.S. Savings and Loan League, 1974.

11. All state chartered savings and loan associations possess general incidental powers, either by specific legislation, W. Prather, Savings Accounts 606 (4th ed. 1970); see, e.g., Fla. Stat. Ann. § 665.214(12) (Supp. 1974); Pa. Stat. Ann. tit. 7, § 6020-101(13) (Supp. 1974), or under well established judicial doctrine, see American Cas. Co. v. Dakota Tractor \& Equip. Co., 234 F. Supp. 606, 610 (D.N.D. 1964); Greenwich Water Co. v. Adams, 145 Conn. 535, 541, 144 A.2d 323, 326 (1958); W. PRATHER, supra at 606. 
on the collateral securing a loan. ${ }^{12}$ Nevertheless, several state statutes may prevent the savings and loan association from acting as an insurance agent. State insurance agent licensing statutes in five states, for example, specifically prohibit a savings and loan from obtaining a license to sell property insurance, ${ }^{13}$ and eight others require the insurance agent applicant to be a natural person. ${ }^{14}$ In the remaining jurisdictions, however, savings and loans can apparently qualify under statutes regulating the types of parties that may become agents. ${ }^{15}$

State antirebate statutes constitute another source of licensing regulation. These statutes, which exist in thirty-eight states, prohibit the payment of rebates or other consideration to induce the

12. Goodman v. Perpetual Bldg. Ass'n, 320 F. Supp. 20, 27-28 (D.D.C. 1970); Kerrigan v. Unity Sav. Ass'n, 58 Ill. 2d 20, 25-27, 317 N.E.2d 39, $42-43$ (1974); Chicago Bldg. Soc'y v. Crowell, 65 Ill. 453, 457-58 (1872).

13. Cal. Fin. Code $\S 5500$ (West 1968); Me. Rev. Stat. Ann. tit. 24A, § 1514-A (1974); Mass. AnN. Laws ch. 175, \& 174E (Supp. 1974); N.H. Rev. Stat. AnN. § 384:16-b(II) (Supp. 1973); Vt. Stat. AnN. tit. 8, § 4811 (Supp. 1974).

14. Ala. Cone tit. 28A, § 114 (Supp. 1973); Fla. Stat. Ann. § 636.731(1) (1972); Ga. Code Ann. § 56-802b (1971); Kan. Stat. Ann. § 40-239 (1973); Mo. Ann. Stat. § 375.016(1) (1968); N.J. Stat. AnN. § 17:22-6.1 (1970); W. VA. Code ANN. § 33-12-2(a) (1972); Wis. STAT. ANN. §§ 209.04(1), (6) (Supp. 1974).

15. Twenty-eight states allow a corporation to be an insurance agent. Alaska Stat. § 21.27.140 (1970); Ariz. Rev. Stat. Ann. § 20-282 (1956); ARk. Stat. AnN. § 66-2802 (1966); Conn. Gen. Stat. Ann. § 38-72 (Supp. 1974); Del. Code Ann. tit. 18, § 1702 (Spec. Insurance Pamphlet 1971); HawaII Rev. Laws § 431-368 (1968); Idaho Code § 41-1021 (Supp. 1974); Ill. ANn. STat. ch. 73, § 1065.37 (Smith-Hurd Supp. 1974); IND. AnN. Stat. § 39-4501 (1965); Ky. Rev. Stat. ANn. § 304.9-020 (1972); La. Rev. Stat. § 22-1161 (1959); Md. AnN. Code art. 48A, § 168(d) (1972); Mont. Rev. Codes ANN. § 40-3302 (1947); Nev. Rev. Stat. § 683A.030 (1973); N.M. Stat. ANN. \$ 58-5-23 (1953); N.Y. INs. Law § 115(2) (McKinney 1966); N.C. Gen. Stat. § 58-39.4 (1965); Ohro Rev. Code ANN. §§ 3905.01, 3905.05 (Anderson 1970); OKLA. Stat. ANN. tit. 36, § 1301 (1958); Ore. Rev. Stat. § 744.135 (1974); PA. Stat. tit. 40, § 231 (1971); S.C. Code AnN. § 37-231.1 (Supp. 1973); S.D. Compiled Laws Ann. § 58-30-1 (1967); Tex. Rev. Civ. Stat. art. 21.14, § 3(a) (Supp. 1974); Utah Code AnN. \$ 31-17-9(2) (Supp. 1973); VA. Code AnN. § 38.1-280 (1970); Wash. Rev. Code § 48.17 .090 (1961); Wyo. Star. ANN. § 26.1-154 (1967). But it should be noted that Nevada and New York prohibit a subsidiary that provides services for a savings and loan from selling property insurance. Nev. Rev. Stat. $\S 673.2765$ (1) (1973); N.Y. INs. LAw \& 7-b (McKinney Supp. 1974). It is unlikely that a savings and loan association could qualify as an insurance agent in Nevada and New York within the scope of the term "corporations"; otherwise, an association would be prohibited from selling insurance through a subsidiary, but permitted to do so directly.

Although nine other states permit only "persons" to qualify for a license, each defines that term to include corporations. Colo. REv. STat. ANN. \$\$ 72-1-19, 135-1-2(8) (1963); Iowa Code ANN. §§ 515.124 (1949), 4.1(13) (1967); Mich. STAT. ANN. §§ 2.212(12) (1969), 24.11201 (1972); Minn. Stat. ANn. $\S \S 60 A .02$, subd. 7 (1968), 645.44, subd. 6 (1947); Miss. Code ANN. \$§ 1-3-39, 83-17-1 (1972); Neb. Rev. Stat. § 44-330 (1974); N.D. Cent. CoDE $\S \S 1-01-28$ (1959), 26-17-.01.3 (1970); R.I. GEN. LAwS ANN. §§ 27-3-1 (1968), 43-3-6 (1970); TENN. CoDE ANN. §§ 1-305(14) (1971), 56-902 (1968).

The District of Columbia has an express provision allowing a savings and loan association to be an insurance agent. D.C. CODE ENCYCL. ANN. § 35-1336 (1968). 
purchase of property insurance. ${ }^{16}$ These statutes restrict competition by prohibiting agents from offering to return to policyholders a portion of the commissions they have earned as an inducement to purchase the insurance through them. ${ }^{17}$ It can be argued that because a savings and loan association acting as an insurance agent might distribute a portion of its commissions, through interest payments to depositors or dividends to stockholders, to some persons who have purchased insurance from it, the savings and loan would violate the antirebate statute. ${ }^{18}$ Establishing a violation of the statute, however, would require proof that the alleged rebate actually induced the purchase of insurance through the savings and loan association, rather than through another agent. ${ }^{19}$ It is unlikely that the uncertain prospect of a minimal and diluted increase in distributed earnings would provide the requisite inducement. ${ }^{20}$

Controlled business statutes, another type of antirebate statute, ${ }^{21}$ prohibit the licensing of an applicant who intends to write

16. Nineteen states have general antirebate statutes covering property as well as other types of insurance. CAL. INS. CODE $\S 750$ (West 1972); GA. CODE ANN. § 56-704(8)(a) (1971); Hawair Rev. Laws \& 431-643(8) (1968); Idaho Code § 41-1314(1) (Supp. 1974); Ind. ANN. Stat. \& 39-5304(8)(a) (Supp. 1974); Ky. Rev. Stat. § 304.12-090(1) (1970); Mass. Gen. Laws AnN. ch. 175, § 182 (1970); Minn. Stat. AnN. $\$ 724.08(1)$ (1968); Neb. Rev. Stat. § 44-361 (1974); N.H. Rev. Stat.AnN. \& 402:39 (1968); N.Y. INS. Law \$ 1881(1) (McKinney 1966); N.C. Gen. Star. § 58-44.5 (1965); OkLa. Stat. Ann. tit. 36, § 12-4(8)(a) (Supp. 1974); Ore. Rev. Stat. \$ 746.045 (1974); Pa. Stat. ANN. tit. 40, § 275 (1971); Utah Code AnN. \$ 31-27-14 (1966); Vt. Stat. AnN. tit. 8, § 4724(8)(A) (Supp. 1974); VA. Code ANN. § 38.1-52(8)(a) (1970); Wash. Rev. Code ANN. § 48.30.140(1) (1961). An additional nineteen states have antirebate laws specifically covering property insurance. Ala. Code tit. 28A, \$ 151(4) (Supp. 1973); Alaska Stat. \$ 21.36.120(a) (1974); Ariz. Rev. Stat. Ann. \$ $20-451$ (1956); ARk. Stat. AnN. \$ 66-3019(1)(1966); Del. Code Ann. tit. 18, § 2312 (a) (Supp. 1970); D. C. Code Encycl. ANN. \$ 35-12-1 (Supp. 1974); Fla. Stat. ANn. § 626.965(1) (1972); Ill. ANn. STat. ch. 73, § 1065.18-29 (Smith-Hurd Supp. 1974); Iowa Code Ann. \& 515A.16 (Supp. 1974); Kan. Stat. ANn. \& 40-941 (1973); Me. Rev. Stat. Ann. tit. 24-A, § 2162(1) (1964); MD. Ann. Code art. 48A, § 226(a) (1972); Miss. CODE ANN. \$ 83-3-33 (1972) (fire insurance); MONT. Rev. CODEs ANN. \$ 40-3512(1) (1961); Nev. Rev. Stat. \$ 686A.130(1) (1973); N.D. Cent. Code § 26-29-15 (1970); Tex. Ins. Code AnN. art. 21.14(22) (1963); W. VA. Code ANN. § 33-11-11 (1972); Wyo. Stat. ANN. 26.1-254(a) (1967). Illegal rebating is usually grounds for revocation of an agent's license. See, e.g., Ariz. Rev. Stat. AnN. § 20-316(A)(2) (Supp. 1974); Ill. Ann. Stat. ch. 73, § 1065.49(a) (Smith-Hurd Supp. 1974); MD. ANN. CoDE art. 48A, § 175(1) (1972).

17. See, e.g., Arcim Corp. v. Pink, 253 App. Div. 428, 429, 2 N.Y.S.2d 709, 711 (1938), aff'd, 280 N.Y. 721, 21 N.E.2d 213 (1939); Moser v. Pantages, 96 Wash. 65, 69, 164 P. 768,769 (1917); E. Patterson, The Insurance Commissioner in the United States 30709, 312 (1927). See also Smith v. Kleinschmidt, 57 Mont. 237, 245, 187 P. 894, 896 (1920).

18. Cf. Goodman v. Perpetual Bldg. Ass'n, 320 F. Supp. 20, 35 (D.D.C. 1970); People ex rel. Troxell v. Baylor, 15 Ill. App. 3d 815, 819-20, 305 N.E.2d 15, 19 (1973).

19. See authorities cited note 17 supra.

20. See Goodman v. Perpetual Bldg. Ass'n, 320 F. Supp. 20, 35 (D.D.C. 1970).

21. Kimball \& Jackson, supra note 7, at 149. 
or place more than a designated percentage of his insurance on controlled business, ${ }^{22}$ which is usually broadly defined to include insurance sales on the property of the agent, his relatives, his employees or employer, or of members, officers, and directors if the agent is an organization. These statutes create an irrebuttable presumption of illegal rebating when more than the designated percentage of an agent's insurance sales are to controlled parties. ${ }^{23}$ The purpose of these statutes, like that of antirebate statutes, is to minimize the number of licenses granted to applicants that intend to obtain insurance for themselves or persons or organizations beneficially connected with them at effective prices lower than those stated in the policies. ${ }^{24}$ Since the diluted return of insurance commissions through distributions of earnings by a savings and

22. Thirty-seven states have enacted controlled business statutes. ALA. Code tit. 28A, § 120(7) (Supp. 1974); Alaska Stat. \& 21.27 .030 (1966); Ariz. Rev. Stat. ANn. § 20-290(7) (1956); ARk. Stat. ANn. $\$ 66-2810(1)($ h) (1966); Cal. Ins. Code $\S 760$ (West 1972); Colo. Rev. Stat. Ann. § 72-1-60(1) (Supp. 1967); Conn. Gen. Stat. Ann. § 38-72 (1958); Del. Code AnN. tit. 18, \& 1710(b) (Supp. 1970); D.C. Code Encycl. ANn. \& 35-1340(e)(f) (1968); Fla. Stat. AnN. $\$ 626.730$ (1972); Ga. Code AnN. 56-804b(1)(b) (1971); Hawail Rev. Laws § 431-366(a) (1968); Idaho Code § 41-1033(2) (Supp. 1974); Ill. AnN. Stat. ch. 73, § 1065.55 (Smith-Hurd 1965); IND. ANN. STAT. § 39-4503(f) (1965) (no percentage designated); Ky. Rev. Stat. § 304.9-100 (1972); La. Rev. Stat. AnN. § 22:1167(C)(8) (Supp. 1974); ME. Rev. Stat. ANN. tit. 24A, §§ 1514, 1603(6) (1974); Miss. Code ANN. § 83-17-205(3) (1973); Mont. Rev. Codes Ann. \$ 40-3308(h) (Supp. Vol. 3, 1961); Neb. Rev. Stat. § 44-361.01 (1974); N.J. Stat. ANN. \& 17:22-6.9(h) (1970) (no percentage designated); N.Y. INS. LAW \& 114(4) (McKinney 1966); N.C. GEN. STAT. \& 58-41(6) (1965); Ohio Rev. Code ANn. $\$ 3905.01$ (Anderson 1970) (no percentage designated); OkLA. Stat. AnN. tit. 36, \& 1309(7) (Supp. 1974) (no percentage designated); Ore. Rev. Stat. § 746.065 (1974); R.I. GEN. LAwS ANN. § 27-3-3 (1968) (no percentage designated); S.C. Code AnN. $\$ 37-242$ (1962); S.D. Compiled Laws Ann. \$ 58-30-38 (1967); Tenn. Code AnN. § 56-912(B) (1968); TeX. INS. Code art. 21.14, § (3)(b) (Supp. 1974); UTAH Code AnN. § 31-17-23 (1953); VA. Code Ann. § 38.1-311(7) (1970); Wash. Rev. Code AnN. $\$ 48.17 .080$ (1961); W. VA. Code ANn. $\$ 33-12-2(d)$ (1972); Wyo. Stat. AnN. $\S 26.1-163(\mathrm{~b})$ (c) (1967). See Kimball \& Jackson, supra note 7, at 149.

23. See, e.g., CaL. INS. Code $\S 760$ (West 1972); Conn. Gen. Stat. Ann. \$ 38-72 (1969).

24. Goodman v. Perpetual BIdg. Ass'n, 320 F. Supp. 20, 33-34 (D.D.C. 1970); Quetnick v. McConnell, 154 Cal. App. 2d 112, 116-17, 315 P.2d 718, 721 (1957); Florida Ass'n of Ins. Agents v. Larson, 155 Fla. 13, 14, 19 So.2d 414, 415 (1944). See also Del. Code ANN. tit. 18, § 1710(a) (Supp. 1971); IdaHo Code § 41-1033(1) (Supp. 1974).

A minority view is that the purpose of controlled business statutes is to prevent the diversion of insurance business from full-time agents by part-time agents who gain access to insurance purchasers through the sale of other products and services. See Jarus v. Robinson, 71 Ohio L. Abs. 510, 512, 133 N.E.2d 441, $442-43$ (C.P. 1954) (real estate broker); Motors Ins. Corp. v. Robinson, 62 Ohio L. Abs. 58, 69, 71-72, 106 N.E.2d 572, 579, 580 (C.P. 1951), aff'd, 62 Ohio L. Abs. 72, 106 N.E.2d 581 (1951), appeal dismissed per curiam, 344 U.S. 803 (1952) (automobile dealer). See also Board of Ins. Comm'rs v. Duncan, 174 S.W.2d 326, 328-29 (Tex. Civ. App. 1943), which states that the purpose of the controlled business statute in question is to preserve free choice in the selection of insurance agents. It is arguable that in the jurisdictions accepting the minority rule, it 
loan association would probably not induce the purchase of insurance from the association, a controlled business statute's presumption of illegal rebating is inappropriate in the savings and loan context. ${ }^{25}$ In fact, twelve states have enacted provisions that specifically exempt insurance sales generated by mortgage transactions from their controlled business statutes. ${ }^{26}$ In states without such provisions, controlled business statutes should be construed to allow a savings and loan association to act as an insurance agent. ${ }^{27}$

Finally, two states have enacted statutes that prohibit the licensing of an applicant that has no intention of deriving a major portion of its income from insurance sales. ${ }^{28} \mathrm{~A}$ savings and loan association is apparently unable to qualify for an insurance agent license in states that have enacted these primary occupation statutes. ${ }^{29}$

would be proper to deny a savings and loan a license under a controlled business statute, since it would be especially easy for the savings and loan to divert insurance sales to itself. On the uniquely advantageous access that savings and loans have to borrowers, see text and notes at notes $66 \& 69$ infra.

25. "[A]ny benefits, direct or indirect, to the individual members of the savings and loan association who pay the insurance premiums are so remote as to be inconsequential." Goodman v. Perpetual Bldg. Ass'n, 320 F. Supp. 20, 34 (D.D.C. 1970) (construing the District of Columbia controlled business statute).

26. Ariz. Rev. Stat. Ann. \& 20-290(7) (1956); Del. Code Ann. tit. 18, § 1710(e) (Supp. 1970); Fla. Stat. AnN. \$626.730 (1970); Ky. Rev. Stat. § 304.9-100(4)(b) (1968); Me. Rev. Stat. Ann. tit. 24-A, \$ 1514(4)(B) (1974); Miss. Code Ann. $\$ 83-17-205(3)$ (1973); Okla. Stat. Ann. tit. 36, § 1309(7) (Supp. 1974); S.D. Compiled Laws Ann. § 58-30-40 (1967); TENN. Code ANN. § 56-912(B) (1968); VT. STAt. ANN. tit. 8, § 4795(b) (Supp. 1974); W. VA. Code ANN. \$ 33-12-2(d) (1972); Wyo. Stat. ANn. § 26.1-163(e)(ii) (1967).

27. A number of state controlled business statutes do not define terms like "association" and "member." See, e.g., Cal. Ins. Code $\$ 760$ (West 1972); Colo. Rev. Stat. Ann. $\S$ 72-1-60(2)(b) (Supp. 1967); Conn. Gen. Stat. AnN. § 38-72 (Supp. 1974); Ga. Code AnN. § 56-801a(9) (Supp. 1974); Idaho Code \$ 41-1033(2) (Supp. 1974); Ill. ANn. Stat. ch. 73, $\S 1065.55$ (Smith-Hurd 1965); N.Y. INS. LaW \$ 114(4) (McKinney 1966); Ore. Rev. STat. $\S 746.065$ (1974); Utah Code AnN. § 31-17-23 (1953); Wash. Rev. Code ANN. § 48.17.080 (1961). To interpret these terms to include savings and loan associations and their borrowers and depositors would mean that a savings and loan association could qualify for a license only if it expected to write less than the designated percentage-for example, thirty-three and one-third percent in Illinois-of its insurance on the property or risks of borrowers and depositors-an unlikely commercial prospect. See People ex rel. Troxell v. Baylor, 15 Ill. App. 3d 815, 819, 305 N.E.2d 15, 18 (1973); Kerrigan v. Unity Sav. Ass'n, 11 Ill. App. 3d 766, 772, 297 N.E.2d 699, 703 (1973), aff'd in part and rev'd in part, 58 Ill. 2d 20,317 N.E.2d 39 (1974). Of course, there is no reason to interpret these undefined terms to include savings and loan associations and their borrowers and depositors if one accepts the majority (antirebate) interpretation of the purpose of controlled business regulation. See text and note at note 24 supra.

28. Mo. AnN. Code art. 48A, \$§ 168(a), (d) (1972); N.J. Stat. ANn. \& 17:22-6.9(g) (1970).

29. See Goodman v. Perpetual Bldg. Ass'n, 320 F. Supp. 20, 36 (D.D.C. 1970) (construing Maryland statute). The New Jersey statute excludes from the determination of an 
In summary, state chartered savings and loan associations are directly prohibited from acting as insurance agents in fourteen states. ${ }^{30}$ Antirebate and controlled business statutes, although they arguably prohibit such activity indirectly in other states, should not be construed to do so.

2. Investment in a Service Corporation that Functions as an Insurance Agent. Several states have enacted legislation that authorizes state chartered savings and loan associations to invest in service corporations that perform a variety of clerical, accounting, and related services. ${ }^{31}$ This legislation usually enumerates several activities that a service corporation may engage in without authori-

applicant's primary occupation consideration of any portion of the agent's business having a connection with a corporation "whose principal business is lending of money." But an applicant for an agent's license must also be a natural person under New Jersey law, and a savings and loan association could thus not qualify. See N.J. Stat. AnN. $\S 17: 22-6.1(1970)$.

30. The fourteen states include the five that specifically prohibit savings and loans from obtaining licenses, the eight that require applicants to be natural persons, and the two that have enacted primary occupation statutes, of which New Jersey also has enacted a natural person applicant requirement.

31. Seventeen states have enacted statutes expressly authorizing investment in service "corporations." Ariz. Rev. Stat. AnN. § 6-446(5) (1974); CaL. Fin. Code § 6702.1 (West 1968); Conn. Gen. Stat. Ann. § 36-178(p) (1958); Hawair Rev. Laws § 407-95 (Supp. 1971); Ill. AnN. Stat. ch. 32, § 706(c) (Smith-Hurd Supp. 1974); Ind. Stat. Ann. § 28-1-21-2(1) (1973); Towa Code AnN. § 534.19(15) (Supp. 1974); Md. Ann. Code art. 23, $\S 161 z$ (b)(2) (1972); Mo. AnN. Stat. § 369.219(6) (Supp. 1974); Neb. Rev. Stat. § 8-320-01 (1970); N.H. Rev. Stat. Ann. § 304:16-b(I) (Supp. 1973); N.Y. Banking Law § 379-a (McKinney 1966); N.D. Cent. Code § 7-02-13 (Supp. 1973); Ohio Rev. Code ANN. § 1151.34(E) (Anderson 1968); PA. STat. ANN. tit. 7, § 6020-162(n) (Supp. 1974); S.C. Code ANN. § 8-612 (Supp. 1974); VA. Code ANN. § 6.1-195.34(e) (1973). Nine states permit a savings and loan to invest in noncorporate service organizations as well as service corporations. Alaska Stat. § 06.30.610(9) (1962); Fla. Stat. ANN. § 665.361(3) (Supp. 1974); La. Stat. Ann. $\S 6.731(\mathrm{~L})$ (Supp. 1974); Mass. Ann. Laws ch. 167, § 51 B (1970); Mich. Stat. ANn. § 23.540(352) (1971); MinN. Stat. Ann. § 51A.35(b) (1970); Tenn. Code Ann. \& 45-1404(c)(1) (Supp. 1974); Tex. Rev. Civ. Stat. art. 852a, § 5.11 (1964); Wis. STat. ANn. § 215.13(26)(f) (Supp. 1974). This comment will use the term service corporation to refer to both service corporations and service organizations.

Several states have also enacted "tie-in" statutes that define the investment powers of state savings and loan associations according to the investment powers that can be exercised by a federal association domiciled in that state. See Harth \& Weeks, Statutory Lending Powers of State Associations, 36 Leg. Bull. $179-447$ (U.S. Sav. \& Loan League 1970) (analyzing the thirty-two tie-in statutes on record in 1970); TENN. CodE ANN. § 45-1409 (Supp. 1974). It is important to note that these statutes add nothing to the preexisting authority of state associations to invest in service corporations that sell insurance, because federal statutes authorize federal associations to invest in service corporations only when an association chartered by the state in which the federal association is domiciled is permitted to do so under state law. See Home Owners' Loan Act of 1933, 12 U.S.C. $\S$ 1464(c) (1970); McCarran-Ferguson Insurance Regulation Act, 15 U.S.C. \$§ 1011 et seq. (1970) (McCarran-Ferguson Act); text and notes at notes 43-63 infra. This analysis is consistent with the purpose underlying state savings and loan "tie-in" legislation: the preservation of a relationship of competitive equality between state and federal associa- 
zation from the savings and loan commissioner. ${ }^{32}$ Although seven states' statutes expressly exclude the sale of property insurance from those activities, ${ }^{33}$ none of the others expressly authorizes service corporations to sell insurance. Each statute, however, confers discretion upon the state savings and loan commissioner to determine what nonspecified activities may be undertaken, and several state commissioners have authorized the sale of property insurance by service corporations. ${ }^{34}$

The validity of a commissioner's determination depends upon whether the statutory delegation of legislative decision making power contains adequate standards to guide the commissioner in exercising his discretion. Statutes that confer authority upon the commissioner without providing any standards are subject to strong constitutional challenge. ${ }^{35}$ When standards are provided, however, it is difficult to determine how extensive they must be for the delegation to be valid; a coherent definition of "adequate

tions doing business in the same state. See Weeks, "Tie-in" Legislation: A Triple-Edged Threat, 30 LEG. BUL. 9, 18-19 (U.S. Sav. \& Loan League 1964).

32. See, e.g., U.S. Savings and Loan League, Model Savings association Act $\S 2$ (v) (I966).

33. Cal. Fin. Code $\S 6702.1$ (West 1968), Me. Rev. Stat. Ann. tit. 24-A, § 1514 (1974); Mass. ANn. Laws ch. 175, § 174E (Supp. 1974); Nev. Rev. Stat. \& 673.2765(1) (1973); N.H. Rev. Stat. ANN. \$ 384:16(b)(II) (Supp. 1973); N.Y. Ins. LaW \$ 7-b (McKinney Supp. 1974); Vt. Stat. Ann. tit. 8, § 4811 (Supp. 1974). Compare notes 13 and 15 supra.

34. At least eight commissioners have done so. Letter from Richard W. Koeb, Superintendent of Banks, State Banking Department, Arizona, May 29, 1974; Letter from J.J. Battaglia, Chief Examiner, Office of the Savings and Loan Commissioner, Illinois, May 27, 1974; Letter from Richard E. Wiles, Supervisor, Building and Loan Division, Department of Financial Institutions, Indiana, May 24, 1974; Letter from Clement S. Ruf, Deputy Supervisor, State Banking Department, Louisiana, May 27, 1974; Letter from Thomas H. Eminizer, Director, Department of Licensing and Regulation, Division of Building, Savings and Loan Associations, Maryland, June 3, 1974; Letter from Anna I. Coppin, Acting Supervisor, Division of Savings and Loan Supervision, Department of Business Administration, Missouri, June 3, 1974; Letter from Douglas J. Westervelt, Chief Examiner, Division of Building and Loan Associations, Department of Commerce, Ohio, June 4, 1974; Letter from William R. Hotz, General Counsel, Office of Commissioner of Savings and Loan, Wisconsin, June 11, 1974. These letters, and all other letters cited in this comment, are on file at The University of Chicago Law Review.

35. State courts have invoked the doctrine of unconstitutional delegation to invalidate, or to construe narrowly, statutory grants of discretion that are overly vague. See, e.g., Krol v. County of Will, 38 Ill. 2d 587, 592-93, 233 N.E.2d 417, 420 (1968) (law vesting standardless power in Health Authority to approve sewage treatment systems declared void); Clean Air Constituency v. California State Air Resources Bd., 11 Cal. 3d 801, 817-20, 523 P.2d 617, 626-28, 114 Cal. Rptr. 577, 586-88 (1974) (pollution control law construed not to authorize administrator to delay enforcement on theory that delay would constitute a fundamental policy decision made without statutory standards).

At least two state service corporation investment statutes provide no explicit standard for authorizing service corporation activities. Mo. ANN. STAT. § 369.219(6) (Supp. 1974); Pa. Stat. Ann. tit. 7, § 6020-162(n) (Supp. 1974). 
standards" has thus far eluded the state courts. ${ }^{36}$ At least some courts have construed the requirement broadly, upholding legislation providing only extremely nonspecific standards. ${ }^{37}$

It could also be argued that a commissioner would lack authority to permit service corporations to sell property insurance in states that have enacted antirebate statutes, controlled business statutes, or primary occupation statutes. But if the application of antirebate and controlled business statutes to savings and loan associations that sell insurance themselves is unjustified in light of the purpose of the statutes, they should not be applied to prevent the sale of property insurance by service corporations, since the same dilution of commissions through distribution of earnings would occur. Furthermore, although primary occupation statutes directly prohibit savings and loans from acting as insurance agents, it is possible to structure the activities of a service corporation to enable it to escape that prohibition. ${ }^{38}$

Thus, in the seven states that expressly prohibit service corporations from selling property insurance, in eight others that require an insurance agent applicant to be a natural person, ${ }^{39}$ and in those other states in which statutes permitting authorization of

36. I K. Davis, Administrative Law Treatise $\S 2.07$ (1958).

37. See, e.g., Sleepy Hollow Lake, Inc. v. Public Serv. Comm'n, 43 App. Div. 2d 439, 444, 352 N.Y.S.2d 274, 278-79 (1974) ("public interest" held adequate standard); Commonwealth v. Cherney, 454 Pa. 285, 291-92 \& n.11, 312 A.2d 38, 41-42 \& n.11 (1973) ("safety" held adequate, citing other cases holding "best interest of educational system" and "blighted" adequate).

Some courts have substituted a requirement of procedural and judicial safeguards against improper agency action for the adequate standards requirement. See, e.g., Motyka v. McCorkle, 58 N.J. 165, 177-78, 276 A.2d 129, 135-36 (1971). See generally Davis, A New Approach to Delegation, 36 U. CHI. L. Rev. 713, 725-30 (1969).

38. But the settled rule prohibiting use of the corporate device to circumvent legislative policy might preclude property insurance activity by service corporations. See Washington Agency v. Insurance Comm'r, 309 Mich. 683, 16 N.W.2d 121 (1944) (license of corporate insurance agent revoked where agent's shareholders owned national bank and state and federal law prohibited national bank from obtaining license directly). See also 1 W. Fletcher, supra note $9, \S 41$; Note, Is The Problem of Disregarding The Corporate Entity More a Question of Law than of Fact? 11 Sr. JoHn's L. REv. 294, 298-302 (1937).

Where, however, there is clear evidence of a legislative intent that service corporations be allowed to sell property insurance, service corporation statutes may be construed as impliedly repealing prior restrictions that might have been interpreted to prevent these corporations from acting as insurance agents, although there is a strong presumption against repeal by implication. See Silver v. New York Stock Exch., 373 U.S. 341, 357 (1963); State ex rel. Galloway v. Industrial Comm'n, 134 Ohio 496, 499-500, 17 N.E.2d 918 (1938); 1A J.G. Sutherland, Statutes and Statutory Construction $\$ 23.10$ (4th ed. 1973).

39. But compare Mo. ANN. STAT. $\$ 375.016(1)$ (1968) (natural person requirement), with Letter from Anna I. Coppin, Acting Supervisor, Division of Savings and Loan Supervision, Department of Business Administration, Missouri, June 3, 1974 (enclosing depart- 
insurance sales by state savings and loan commissioners are subject to invalidation as unconstitutional delegations of legislative power, savings and loan service corporations are prohibited from acting as insurance agents.

3. Subsidiaries of Savings and Loan Holding Companies as Insurance Agents. The Savings and Loan Holding Company Amendments of 1967 (Holding Company Amendments) ${ }^{40}$ authorize a holding company ${ }^{41}$ to operate subsidiaries that sell insurance. ${ }^{42}$ But the effect of these Amendments on existing state regulation of the sale of property insurance by state chartered savings and loan associations is governed by section 2(b) of the McCarranFerguson Insurance Regulation Act (McCarran-Ferguson Act), ${ }^{43}$ which provides that no federal statute shall be construed to invalidate, impair, or supersede state statutes that regulate the business of insurance unless the federal statute itself "specifically relates to the business of insurance." ${ }^{44}$ In SEC v. National Securi-

ment Regulations that expressly allow service corporations to act as insurance agents, but limit service corporations" powers to those permitted under state law). Compare Wis. STAT. ANN. \$§ 209.04(1), (6) (Supp. 1974) (natural person requirement), with Letter from William R. Hotz, General Counsel, Office of Commissioner of Savings and Loan, Wisconsin, June 11, 1974 (enclosing Guidelines that indicate that a service corporation may own and operate an insurance agency).

40. 12 U.S.C. \$ 1730 a (1970).

41. By the end of 1966 , there were 98 holding companies controlling 134 associations. These associations controlled 12.5 percent of the assets in the savings and loan industry. Hearings on S. 1542 Before the Senate Comm. on Banking and Currency, 90th Cong., Ist Sess. 25 (1967). All controlled savings and loan subsidiaries are state chartered. Letter from Charles E. Allen, General Counsel, Federal Home Loan Bank Board, Washington, D.C., June 6, 1974. See also National Association of Insurance Agents, Study of Insurance Agency Activities of SAvings and Loan Associations 18-19 (1972) [hereinafter cited as NAIA STUDY].

42. The Holding Company Amendments distinguish between a savings and loan holding company and a multiple savings and loan holding company; the former controls "an insured institution" while the latter controls "two or more insured institutions." 12 U.S.C. $\S \S 1730 \mathrm{a}(\mathrm{a})(1)(\mathrm{D}),(\mathrm{E})(1970)$. An insured institution is one whose accounts are insured by the Federal Savings and Loan Insurance Corporation (FSLIC). 12 U.S.C. $\&$ I724(a) (1970). Approximately sixty-six percent of all state chartered associations controlling almost ninety-four percent of the assets held by state chartered associations, are FSLICinsured. See FAct Book, supra note 1, at 57-58. Although the Holding Company Amendments contain a provision restricting the activity of multiple holding companies, 12 U.S.C. $\S 1730 \mathrm{a}(\mathrm{c})(2)(1970)$, they expressly allow a multiple holding company to control a noninsured subsidiary that sells insurance. Id. $\$ 1730 \mathrm{a}(\mathrm{c})(2)(\mathrm{B})$. There are no provisions in the Holding Company Amendments that either permit or prohibit an insured subsidiary of a multiple savings and loan company, or any subsidiary of a holding company controlling only one insured institution, from engaging in this activity.

43. Act of Mar. 9, 1945, ch. 20, § 2(b), 59 Stat. 34, as amended, 15 U.S.C. $\S 1012$ (b) (1970).

44. Id. See Hamilton Life Ins. Co. v. Republic Nat'l Life Ins. Co., 408 F.2d 606, 611 (2d Cir. 1969). 
ties, Inc., ${ }^{45}$ the Supreme Court noted that the core of the "business of insurance" is the relationship between the insurance company and the policyholder. ${ }^{46}$ Thus, although the Holding Company Amendments relate to "insurance" in that they authorize control over subsidiaries that act as insurance agents, they do not relate to the "business of insurance" within the meaning of the McCarran-Ferguson Act. The central concern of the Amendments is the regulation of the investment activities of holding companies, not the licensing of insurance agents, which the Court held to be an activity within the business of insurance. ${ }^{47}$

Consequently, if a state statute prohibits the issuance of an insurance agent license to the subsidiary of a savings and loan holding company, the state statute governs, and the Holding Company Act Amendments' authorization of investment in insurance agent subsidiaries could not be construed to invalidate, impair, or supersede it. Moreover, a savings and loan holding company would be unable to operate an insurance agent subsidiary in states that merely prohibit a savings and loan association from investing in a service corporation that sells insurance. The Holding Company Amendments explicitly prohibit a savings and loan holding company and its subsidiaries other than insured savings and loans from performing services for the purpose or with the effect of evading state laws or regulations applicable to insured subsidiaries of the holding company. ${ }^{48}$

45. 393 U.S. 453 (1960).

46. Id. at 460 .

47. Id.

48. 12 U.S.C. $\$ 1730 \mathrm{a}(\mathrm{c})(1)(1970)$. Ownership of an insurance agency by a savings and loan holding company is apparently common. See Hearings on S. 1542 Before the Senate Comm. on Banking and Currency, 90th Cong., 1st Sess. 85 (1967) (testimony that nine of the ten member holding companies of the Council of Savings and Loan Stock Companies controlled at least one insurance agency subsidiary).

More than eighty percent of the assets controlled by savings and loan holding companies are located in California. S. Rep. No. 354, 90th Cong., 1st Sess. 6 (1967). Although no California statute prohibits a non-savings and loan subsidiary from selling insurance, see Cal. Fin. Code $\S \S 11500-11650$ (West 1968), \$§ 11700-11708 (West Supp. 1974), the state's insurance agent licensing statutes prevent both a savings and loan, CAL. FIN. CODE $\S 5500$ (West 1968), and its service corporations, CAL. FIN. CoDE $\S 6702.1$ (West 1968), from obtaining licenses. Thus, permitting a savings and loan holding company to operate a non-savings and loan subsidiary that sells insurance would circumvent the state's policy against insurance sales by savings and loan associations and their service corporations and should be prohibited. $C f$. Jackson v. First Nat'l Bank, 430 F.2d 1200 (5th Cir. 1970), cert. denied, 401 U.S. 947 (1971) (one bank holding company forced to give up its armored car service because ownership of that service by a bank would have violated the state's branch banking laws). 


\section{B. Federal Associations}

1. The Association as an Insurance Agent. The Home Owners' Loan Act of 1933,49 which provides for the incorporation and regulation of federal savings and loan associations, ${ }^{50}$ does not specifically authorize a federal association to function as an insurance agent. Nor does the Act expressly grant a federal association those incidental powers reasonably necessary to accomplish its express objects and purposes. ${ }^{51}$ The Federal Home Loan Bank Board (FHLBB) has construed its own powers under the Act as including the power to grant federal associations a wide range of incidental powers, ${ }^{52}$ but it has interpreted those powers to exclude the authority to sell property insurance. ${ }^{53}$ As a result, federally chartered savings and loan associations, constituting almost thirty-nine percent of all associations and holding fiftysix percent of the industry's assets, ${ }^{54}$ are prohibited from acting as property insurance agents.

2. Investment in a Service Corporation that Functions as an Insurance Agent. The Home Owners' Loan Act was amended in 1964 generally to allow federal associations to invest in service corporations, ${ }^{55}$ and the FHLBB has issued a regulation specifically authorizing investment by a federal association in a service corporation that markets property insurance. ${ }^{56}$ This regulation, however, can-

49. 12 U.S.C. $\$ \S 1461$ et seq. (1970).

50. All federal associations receive their charters from the Federal Home Loan Bank Board (FHLBB), 12 U.S.C. $\S 1464$ (a) (1970), and are organized in mutual corporate form. 12 U.S.C. $\S 1464(\mathrm{~b})(1)(1970) ; 12$ C.F.R. $\$ 544.1$ (1974). These associations are required to have their accounts insured by the FSLIC, 12 U.S.C. $\$ 1726(\mathrm{~b})(1970)$, and they automatically become members of the Federal Home Loan Bank (FHLB) system, 12 U.S.C. $\S 1464(\mathrm{f})$ (1970), which serves as a central bank to supplement the resources of member associations. See 12 U.S.C. \$§ 1429-31 (1970).

51. This is in contrast to Congress's specific grant to national banks of "all such incidental powers as shall be necessary to carry on the business of banking . . ." 12 U.S.C. $\S 24(1970)$.

52. See 12 C.F.R. \& 544.1 (1974) (FHLBB charter provision regulations). An earlier charter (Charter $\mathrm{K}$ ), under which many federal associations still operate, also grants similarly broad powers. See 24 C.F.R. § 202.9(a) (1938).

53. Opinion of Legal Department, FHLBB, May 26, 1936, excerpted in NAIA STudy, supra note 41, at 10; Letter from Charles E. Allen, General Counsel, FHLBB, Washington, D.C., June 6, 1974. See Goodman v. Perpetual Bldg. Ass'n, 320 F. Supp. 20, 28 (D.D.C. 1970) (dictum). There is an indication in some FHLBB opinion letters, however, that an association could operate as an agent if no other reasonable means to insure the property securing the loan were available. See NAIA StUDY, supra note 41 , at 10-12.

54. See $\mathrm{F}_{\mathrm{ACT}} \mathrm{BOOK}$, supra note 1 , at $\mathbf{5 8 .}$

55. Act of Sept. 2, 1964, Pub. L. No. $88-560$, tit. IX, $\S 905,78$ Stat. 805,12 U.S.C. $\S 1464$ (c) (1970).

56. 12 C.F.R. $\$ 545.9-1(a)(4)(x i)(1974)$. 
not authorize a federal association to invest in a service corporation that markets property insurance if state chartered associations in the state in which the federal association is domiciled lack comparable investment authority.

The 1964 amendment, as originally introduced, ${ }^{57}$ contained a provision authorizing federal associations to invest in service corporations subject to "rules and regulations of the Board . . . ."58 The "rules and regulations" limitation was eventually deleted, ${ }^{\mathbf{5 9}}$ thus clearly indicating that Congress had no intention of giving the FHLBB the authority to limit a federal association's power to invest in a service corporation. Under the amendment, a federal association was to have the same power to invest in a service corporation as a state association doing business in the same jurisdiction. ${ }^{60}$

Moreover, the 1964 amendment of the Home Owners' Loan Act, like the Savings and Loan Holding Company Amendments of $1967,{ }^{61}$ is not a statute regulating the business of insurance within the meaning of the McCarran-Ferguson Act. The 1964

57. H.R. 12175, 88th Cong., 2d Sess. (1964). The bill was introduced on July 30, 1964. 110 Cong. Rec. 17479 (1964).

58. 110 Cong. REc. 19332 (1964). The amendment originated in a 1961 bill introduced by Representative Addonizio of New Jersey. H.R. 8647, 87th Cong., 1st Sess. (1961); 107 CoNG. REc. 15393 (1961). Although that bill would have been applicable to all federal savings and loan associations, it was introduced in response to a particular problem that existed in New Jersey. Federal associations in that state had no authority to invest in the Central Corporation of Savings and Loan Associations, which was wholly owned by state chartered associations and which provided member associations with various services related to mortgage transactions. Lefcoe \& Dobson, Savings Associations as Land Developers, 75 YALE L.J. 1271, 1292 n.74 (1966).

59. 110 CoNG. REC. 19332-33 (1964). The limitation on the size of authorized investments was also reduced from two percent to one percent of the association's assets, thereby allegedly reducing the need for FHLBB restriction of a federal association's service corporation activities. Id.

Although both the House and Senate committee reports indicate an intention to limit service corporation activities, H.R. REP. No. 1703, 88th Cong., 2d Sess. 28 (1964), S. REP. No. 1265, 88th Cong., 2d Sess. 55 (1964), both reports had been completed before the elimination of the "rules and regulations" clause. See House Report, supra at 27; Senate REPORT, supra at 54.

60. 110 CONG. REC. 19333 (1964) (remarks of Representative Widnall, sponsor of the amendment). Congress had in other cases limited service corporation powers by express statutory provisions. The Bank Corporation Act, for example, limits the function of certain bank service corporations to clerical and data processing services. Pub. L. 87-856, Oct. 23, 1962, $\$ \S(1)(c),(b), 76$ Stat. 1132, 12 U.S.C. $\$ \S 1861$ (c), (b) (1970). In fact, Congress never enacted H.R. 8245, 88th Cong., lst Sess. $\$ 5$ (1963), a bill that would have limited the service corporation activity of FSLIC-insured savings and loan associations to the clerical and data processing services permitted under the Bank Service Corporation Act. See 12 U.S.C. $\S \S 1861(b), 1864$ (1970).

61. See text and notes at notes 40-48 supra. 
amendment authorizes federal associations to undertake certain investment activity and makes no attempt to regulate the licensing of insurance agents. Thus, it is not open to a construction, either on its face or under regulations promulgated by the FHLBB, ${ }^{62}$ that would impair state insurance agent licensing laws. As a result, a federal association cannot operate a service corporation that sells property insurance if the state in which it is domiciled prohibits a service corporation from selling property insurance. ${ }^{63}$

\section{Policy Considerations}

Although several state insurance agent licensing statutes may apply indirectly to savings and loan associations, their service corporations, and their holding company subsidiaries, this comment has argued that such regulations should be construed to permit the sale of property insurance by these parties. Other regulations directly prohibit the sale of property insurance by state and federally chartered associations and their service corporations. There are several policy grounds that would support the elimination of these restrictions.

The sale of property insurance by a savings and loan association or an affiliate located on its premises, for example, provides increased convenience to the consumer. ${ }^{64}$ The purchase of a home ${ }^{65}$ usually requires three transactions: the procurement of a mortgage, the actual purchase of the real estate, and the purchase of property insurance. If the savings and loan association acting as mortgagee is permitted to sell the insurance, the consumer's purchase would require only two transactions. ${ }^{66}$ Integration of

62. See 12 C.F.R. $\$ 545.9-1$ (a)(4)(xi) (1974).

63. See statutes cited at notes 14 \& 33 supra. The only court holding that a federal association may invest in a service corporation that sells property insurance noted that a state association in that jurisdiction had the same investment powers. People ex rel. Troxell v. Baylor, 15 Ill. App. 3d 815, 820, 305 N.E.2d 15, 19 (1973).

64. At least one commentator has attributed the success of savings and loan management-owned agencies that operate on the association's premises in part to the fact that customers find it more convenient to use an agency on the premises than to patronize an agency at a different location. See Herman, supra note 4, at 854 .

65. The typical savings and loan borrower is an individual homeowner. At the end of 1973, about seventy-five percent of the mortgage loans held by FSLIC-insured associations were secured by single-family homes. FACT BоoK, supra note 1 , at 78 .

66. But it has also been argued that "one-stop shopping" may result in fragmentation of the insurance buying process, that is, purchase of part of a customer's insurance needs from one agent and part from another. The alleged result of fragmentation is that the customer purchases more coverage than he needs or buys inadequate coverage. Even if this were true, one solution would be to allow a financial institution to sell all types of 
the loan purchase with the insurance transaction may also reduce the total cost of providing insurance. Certain information required in mortgage transactions is used in preparing insurance policies, and costs would be reduced whenever the loan personnel could use the initial information to determine the insurable value of the property. ${ }^{67}$

Elimination of restrictions on insurance sales by savings and loan associations will probably increase the number of competing insurance agents, and this increased competition may benefit the consumer. First, it may result in an increase in the quality of various services, such as analysis of client needs, recommendation for coverage, selection of an insurer, and assistance in claim settlement at the time of loss. Second, if increased competition among agents results in a reduction in the size of their commissions, it will probably lead to lower premium charges. ${ }^{68}$

Although these potential benefits of allowing savings and loan associations to act as insurance agents may justify elimination of the various existing licensing restrictions, it provides no justification for allowing savings and loan associations, if they can legally act as agents, to condition the extension of a property loan on the purchase of insurance from the association or an affiliated agency. ${ }^{69}$ There has been some dispute over whether tying arrangements should be viewed as an exclusionary practice or as a monopoly profit maximization device; ${ }^{70}$ nevertheless, they are generally recognized as having anticompetitive effects. Over twenty-five states have already enacted statutes that prohibit con-

insurance and thus serve all of a customer's insurance needs, rather than to prohibit the institution from selling any insurance. Hearings on the Credit Crunch and Reform of Financial Institutions Before the House Comm. on Banking and Currency, 93d Cong., Ist Sess., pt. 2, at 867-68 (1973) (testimony of Emmett J. Vaughan).

67. But see id. at 870-71.

68. For an indication that an increasing number of property insurers feel it necessary to reduce commission expenses in order to maintain prices competitive with other firms, see Kobler, The Florida Manifesto Manifest, 74 Besr's Review (Property/Liability) 14 (1974). For a discussion of the increasing competition in property lines, see Natronal association of Insurance Commisstoners, Monitoring Competition: A Means of Regulating the Property and Liability Business 66-70 (1974) [hereinafter cited as NAIC STUdy]; Rose, State Regulation of Property and Casualty Insurance Rates, 28 OHIo ST. L.J. 669, 720-24 (1967); Rose, Regulation of Property and Casualty Insurance Rates in Ohio, 32 Онго St. L.J. $487,502-03$ (1971).

69. These tying arrangements are common in the savings and loan industry. See Herman, supra note 4, at 854-55; Kimball \& Jackson, supra note 7, at 155.

70. See Posner, Exclusionary Practices and the Antitrust Lauls, 41 U. ChI. L. Rev. 506, 508-15 (1974). See also Bowman, Tying Arrangements and the Leverage Problem, 67 YALE L.J. 19, 21-23 (1957); Burstein, A Theory of Full-Line Forcing, 55 Nw. U.L. REv. 62, 63-64 (1960); Burstein, The Economics of Tie-in Sales, 42 Rev. Econ. \& STat. 68 (1960). 
ditioning the extension of credit upon the purchase of insurance at a designated agency. ${ }^{71}$ Similar federal regulations have been proposed to prohibit the use of tying arrangements by FSLIC-insured institutions. ${ }^{72}$ The federal antitrust laws may also be applicable, since the McCarran-Ferguson Act expressly provides that they apply to the business of insurance to the extent that such business is not regulated by state law. ${ }^{73}$ The coverage of federal antitrust laws, however, is limited. ${ }^{74}$ Moreover, any statutes prohibiting tying arrangements are difficult to enforce because of the apparently widespread use of subtle coercion rather than explicit tying requirements. ${ }^{75}$

71. NAIC Study, supra note 68, at 228. See, e.g., CAL. INs. Code $\$ 770$ (West 1968); Mich. STAT. ANN. \& 24.12077 (1972); N.Y. INS. LAw \& 7-a (McKinney Supp. 1973).

72. Proposed Ins. Reg. \$ 563.35(a)(1), 39 Fed. Reg. 42390 (1974).

73. 15 U.S.C. $\$ 1012$ (b) (1970). One federal court has held that federal antitrust laws apply without limitation, since the fact that an insurance policy is the tied product does not bring the tying arrangement within the meaning of the "business of insurance," nor therefore within exclusive state regulation under the Act. Fry v. John Hancock Mut. Life Ins. Co., 355 F. Supp. 1151, 1154 (N.D. Tex. 1973); see SEC v. National Securities Inc., 393 U.S. 453, 458-60 (1969). But see Note, Federal Regulation of Insurance Companies: The Disappearing McCarran Act Exemption, 1973 DukE L.J. 1340, 1352-54.

74. Section 3 of the Clayton Act, 15 U.S.C. $\$ 14$ (1970), is probably inapplicable, since money-lending is not one of the underlying transactions covered by the Act. See United States v. Investor Diversified Servs., Inc., 102 F. Supp. 645, 647-49 (D. Minn. 1952), vacated on other grounds by consent decree, TRADE REG. REP. (1954 Trade Cas.) If 67,799, at 69,574 (D. Minn. June 30, 1954). Section 5(a)(6) of the Federal Trade Commission Act, 15 U.S.C. \& 45(a)(6) (1970), which prohibits unfair methods of competition and unfair or deceptive acts or practices, specifically exempts banks from its coverage. One court has held that the reason for the exemption was that banks are subject to the direction and control of a separate commission largely similar to that of the Federal Trade Commission. T.C. Hurst \& Son v. FTC, 268 F. 874, 877 (E.D. Va. 1920). This rationale has equal force when applied to federal savings and loan associations. The FHLBB has powers over federal asociations similar to those exercised by the Federal Reserve Board over national banks, see T. Marvell, The Federal Home Loan Bank Board 20, 57 (1969), and the FSLIC plays a role analogous to that of the Federal Deposit Insurance Corporation. See id. at 5, 84-86. Moreover, seventy-one percent of all state associations, controlling ninetyfive percent of the assets held by state asociations, are subject to federal regulation either as a member of the FHLB system, or as an FSLIC-insured institution as well. See FACT Воoк, supra note 1, at 57-58, 111-12; 12 U.S.C. \$§ 1464(a), 1725(a) (1970).

Finally, section 1 of the Sherman Act, 15 U.S.C. $\S 1$ (1970), may have only minimal impact on these tying arrangements because it has been interpreted to require that the violator have had substantial market power over the tying product and have restrained a not insubstantial amount of interstate commerce. See Fortner Enterprises, Inc. v. U.S. Steel Corp., 394 U.S. 495 (1969); Spens v. Citizens Fed. Sav. \& Loan Ass'n, 364 F. Supp. 1161,1164 (N.D. Ill. 1973) (individual savings and loan associations had insufficient economic power over loans, the tying product). But cf. Stavrides v. Mellon Nat'l Bank \& Trust Co., 353 F. Supp. 1072, 1076-77 (W.D. Pa. 1973), aff'd, 487 F.2d 953 (3d Cir. 1973).

75. Associations rarely declare explicitly that the borrower has to purchase the required insurance through a designated agency to obtain the loan; the lender probably relies more upon subtle hints. Herman, supra note 4, at 854-855; Kimball \& Jackson, 


\section{CoNCLUSION}

Insurance agent licensing regulations that exist in some states may restrict the sale of property insurance by savings and loan associations and affiliated agencies. This comment has argued that elimination of those restrictions would lead to increased convenience, better service, and lower insurance rates for the consumer. The strongest argument against elimination of these restrictions is that savings and loan associations, if permitted to sell insurance freely, can use subtle pressures in a tight credit market to force the mortgagor to purchase his property insurance through the savings and loan association or an affiliated agency rather than through another agent. But the risk of anticompetitive effects of these tying arrangements can be reduced through more effective enforcement of existing statutes or by other methods such as increasing competition among loan associations by allowing additional entry into the industry. It would be anomalous indeed to attempt to prevent these anticompetitive effects by maintaining direct restrictions on competition.

Jonathan Kahn

supra note 7, at 156. Proving subtle coercion is extremely difficult if the borrower signs a statement conceding that the lender allowed him free choice in the selection of an insurance agent. These forced confessions of "free will" have actually enabled some lenders completely to circumvent statutes that prohibit tying arrangements. See Herman, supra note 4 , at 855 n.9. 